\title{
PENGARUH PDB, INFLASI, TINGKAT SUKU BUNGA DAN NILAI TUKAR RUPIAH TERHADAP INDEKS HARGA SAHAM JAKPROP YANG TERDAFTAR DI BURSA EFEK INDONESIA
}

\author{
Chendra Gunawan \\ Program Studi Magister Manajemen Universitas Tarumanagara \\ chendra_gunawan@hotmail.com \\ Carunia Mulya Firdausy \\ Program Studi Magister Manajemen Universitas Tarumanagara
}

Masuk : 29-11-2017, revisi : 16-12-2017 diterima untuk diterbitkan : 16-12-2017

\begin{abstract}
This research aims to find out and analyze the effects of variable GDP, Inflation, Interest rates, Exchange rate on share prices of listed property sector in Indonesia Stock Exchange. The object population in this study is a company incorporated in the listed Property \& Real Estate Index sector (JAKPROP) in Indonesia Stock Exchange (BEI) from 2008 to 2017. This study uses Ordinary Least Square analysis to determine the effect of independent variables on the Property \& Real Estate Index sector JAKPROP. Based on t test, GDP is significant, Inflation is not significant and BI Interest rate is significant effect, while the variable Exchange rate have a significant effect on property and Real Estate sector stock price index. Results simultaneously with the F test showed that all the independent variable significantly influenced on the stock price index Property \& Real Estate sector. So, the result is the independen variable GDP, Bi-rate \& Exchange-rate has an influence effect on the stock price index of listed Property \& Real Estate sector JAKPROP in Indonesia Stock Exchange.
\end{abstract}

Keywords: Stock Price Index JAKPROP, GDP, Inflation, BI Interest Rate, Exchange Rate

\section{PENDAHULUAN}

Prospek bisnis properti yang semakin berkembang pesat dapat dilihat dari banyaknya pengembangan residential development, commercial development dan juga mixed used development pada CBD Area (central business district) maupun Non-CBD Area (non central business district) yang penyebarannya tersebar luas diseluruh wilayah. Melihat perkembangan bisnis properti yang berkembang pesat mampu menarik minat para investor dan developer (pengembang) untuk berinvestasi di dalam bisnis properti.

Bisnis properti semakin marak diperdagangkan baik dalam bentuk asset (harta tidak bergerak) maupun dalam berbentuk saham yang diperdagangkan di bursa pasar modal. Investasi properti merupakan investasi jangka panjang karena berbentuk fixed asset dan harga properti semakin meningkat sepanjang tahun sehingga kenaikannya tidak terkendali dan pertumbuhannya sangat sensitif terhadap kondisi perekonomian.

Peneliti Pakpahan (dikutip dalam Fuadi, 2009) menunjukkan bahwa sektor properti merupakan salah satu sektor yang paling tinggi volatilitas returnnya. Gunawan (Kompas, Oktober 23, 2013) menulis bahwa Sektor properti di Bursa Efek Indonesia merupakan the best performer dibandingkan kinerja sektor lain seperti perbankan dan consumer goods. Tercatat 5 (lima) besar peringkat teratas emiten saham properti dan real estate yang membukukan keuntungan penjualan diatas 50 persen yaitu; Alam Sutera (ASRI), Bumi Serpong Damai (BSDE), Lippo Karawaci (LPKR), Summarecon Agung (SMRA) dan Pakuwon Jati (PWON).

Sektor properti dan real estate dapat dijadikan tolak ukur pertumbuhan ekonomi suatu negara. Jika kondisi makroekonomi negara tumbuh pesat maka bisnis properti dan real estate juga mengalami pertumbuhan dan juga sebaliknya. Dalam tulisan Diredja (Kompas, Oktober 
25, 2013) menyatakan: "Jika kondisi makroekonomi nasional sedang tumbuh tinggi, bisnis properti ikut menggeliat. Namun, jika ekonomi surut maka industri properti akan ikut surut.

Melihat fenomena diatas penelitian ini mengacu pada saham sektor properti dan real estate yang terdaftar di Bursa Efek Indonesia. Oleh Karena itu, Penelitian ini ditujukan untuk mengkaji pengaruh - pengaruh yang dominan dari variabel Makro Ekonomi (PDB, Inflasi, Tingkat Suku Bunga dan Nilai Tukar Rupiah) terhadap Indeks Harga Saham sektor properti JAKPROP sehingga dapat digunakan sebagai tambahan informasi dan pengetahuan bagi calon investor untuk mengambil keputusan dalam berinvestasi. Bagi emiten, dapat dijadikan bahan pertimbangan dalam menentukan kebijakan - kebijakan strategies di dalam perusahaan.

\section{TINJAUAN PUSTAKA}

Analisis ekonomi dilakukan karena adanya kecenderungan hubungan yang kuat antara apa yang terjadi pada lingkungan ekonomi makro dengan kinerja suatu pasar saham. Siegel (1991) menyimpulkan adanya hubungan yang kuat antara harga saham dan kinerja ekonomi makro dan menemukan bahwa perubahan pada harga saham selalu terjadi sebelum terjadinya perubahan ekonomi.

Perubahan kinerja pasar saham akan mencerminkan apa yang terjadi pada perubahan perekonomian makro. Pasar saham telah dilihat sebagai leading indicator perekonomian, penurunan besar dalam harga saham mungkin akan terjadi resesi masa depan, sedangkan peningkatan besar dalam harga saham mungkin menunjukkan pertumbuhan ekonomi yang kuat di masa depan. Perubahan kinerja pasar saham tidak bisa dipisahkan dengan perubahan yang terjadi pada prospek berbagai perusahaan yang ada di pasar dimana selanjutnya bisa mempengaruhi harga saham dari suatu perusahaan di masa datang. Hal ini didukung oleh argumen bahwa harga saham harus mencerminkan pertumbuhan pendapatan perusahaan di masa depan.

Saham properti adalah salah satu pilihan investasi yang menarik. Industri properti memiliki supply lahan yang terbatas sementara demand-nya terus bertambah. Dengan kondisi tersebut, dalam jangka panjang industri ini akan memilki prospek yang baik. Meningkatnya prospek industri properti akan berdampak pula pada harga sahamnya. Bahkan Gordon et.al (1998) dalam penelitiannya memperlihatkan betapa rata-rata return kuartalan saham properti di Asia lebih tinggi dibanding return ekuitas lainnya. Dengan pertimbangan tersebut, saham di sektor properti layak dipertimbangkan sebagai pilihan investasi.

Penelitian sebelumnya telah memperlihatkan betapa saham sektor properti memiliki korelasi yang signifikan dalam jangka panjang dengan variabel makroekonomi (Nurhidayat, 2009). Peneliti Pakpahan (dikutip dalam Fuadi, 2009) menunjukkan bahwa sektor properti merupakan salah satu sektor yang paling tinggi volatilitas returnnya. Gunawan (Kompas, Oktober 23, 2013) menulis bahwa Sektor properti di Bursa Efek Indonesia merupakan the best performer dibandingkan kinerja sektor lain seperti perbankan dan consumer goods. Tercatat 5 (lima) besar peringkat teratas emiten saham properti dan real estate yang membukukan keuntungan penjualan diatas 50 persen yaitu; Alam Sutera (ASRI), Bumi Serpong Damai (BSDE), Lippo Karawaci (LPKR), Summarecon Agung (SMRA) dan Pakuwon Jati (PWON).

Sektor properti dan real estate dapat dijadikan tolak ukur pertumbuhan ekonomi suatu negara. Jika kondisi makroekonomi negara tumbuh pesat maka bisnis properti dan real estate juga mengalami pertumbuhan dan juga sebaliknya. Dalam tulisan Diredja (Kompas, Oktober 25, 2013) menyatakan: "Jika kondisi makroekonomi nasional sedang tumbuh tinggi, bisnis properti ikut menggeliat. Namun, jika ekonomi surut maka industri properti akan ikut surut.

\section{METODOLOGI PENELITIAN}

Adapun objek yang diteliti adalah perusahaan properti yang terdaftar di Bursa Efek Indonesia dengan periode penelitian 2008-2017. Data - data yang digunakan merupakan data sekunder yang berupa data publikasi yang mana data tersebut telah dikumpulkan oleh pihak 
lain PDB, Inflasi, Tingkat Suku Bunga dan Nilai Tukar Rupiah yang dikutip dari situs resmi Biro Pusat Statistik (BPS), Bank Indonesia (www.BI.go.id) dan closing price indeks harga saham perusahaan properti yang bersumber dari (www.bloomberg.com). Seluruh data - data yang diperlukan lalu diolah dengan menggunakan software SPSS ver 18.00.

Berdasarkan tingkat eksplanasi (level of explanation) atau tingkat penjelasannya, maka penelitian ini dikategorikan sebagai penelitian asosiatif. Penelitian asosiatif merupakan penelitian yang bertujuan untuk mengetahui hubungan antara dua variabel atau lebih (Sugiyono, 2006). Berdasarkan data yang diperoleh, maka penelitian ini termasuk penelitian kuantitatif, karena penelitian ini mengacu pada perhitungan data yang berupa angka-angka. Penelitian ini menggunakan analisis ordinary least square regression atau regresi linier karena merupakan metode regresi yang meminimalkan jumlah kesalahan / error.

Adapun kerangka penelitian ini dapat dilihat pada Bagan Kerangka Pemikiran berikut :

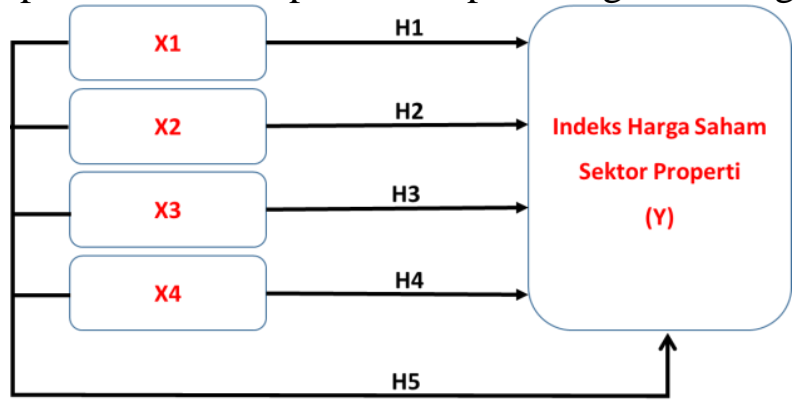

Gambar 1

Kerangka Pemikiran

Sumber: Data diolah oleh peneliti

Keterangan:

X1 : Variabel independen Produk Domestik Bruto.

X2 : Variabel independen Inflasi.

X3 : Variabel Independen Tingkat Suku Bunga.

X4 : Variabel Independen Nilai Tukar Rupiah.

Y : Variabel Dependen Indeks Harga Saham Sektor Properti

Metode Analisis

Model yang digunakan dalam pengujian penelitian ini adalah sebagai berikut:

$$
\mathrm{Y}=a+b 1 X 1+b 2 X 2+b 3 X 3+b 4 X 4+e
$$

Keterangan:

$\mathrm{Y}=$ Indeks harga saham sektor properti

$\mathrm{a}=$ konstanta

$b 1, b 2, b 3, \mathrm{~b} 4=$ koefisien regresi linear

$\mathrm{X} 1=$ Pertumbuhan PDB $(\%)$

$\mathrm{X} 2=$ Inflasi $(\%)$

X3 = Tingkat Suku Bunga $(\%)$

X4 = Nilai tukar US\$ terhadap Rupiah (rupiah)

$\mathrm{e}=$ error term (residual)

Pengujian Hipotesis

Untuk membuktikan hipotesis diterima atau ditolak maka dalam penelitian ini dilakukan pengujian hipotesis, yaitu terdiri dari:

a. Uji Parsial (uji t). Uji t digunakan untuk menguji koefisien regresi secara parsial dari variabel bebas terhadap variabel terikat.

b. Uji Simultan (uji F). Uji F ini merupakan pengujian terhadap signifikansi model secara simultan atau bersama-sama, yaitu melihat pengaruh dari seluruh variabel bebas terhadap variabel terikat.

c. Koefisien determinasi (R2). Pada intinya mengukur seberapa jauh kemampuan model dalam menerangkan variasi variabel dependen. 


\section{ANALISIS DAN BAHASAN TEMUAN}

Statistik Deskriptif

Tabel 1
\begin{tabular}{|l} 
Statistik Deskriptif \\
Descriptive Statistics
\end{tabular}
\begin{tabular}{|l|r|r|r|r|r|}
\hline & \multicolumn{1}{c|}{ Minimum } & Maximum & \multicolumn{1}{c|}{ Mean } & Std. Deviation \\
\hline PDB & 110 & 4.31 & 6.81 & 5.5126 & .72522 \\
INFLASI & 110 & 2.41 & 12.14 & 5.6803 & 2.30743 \\
BI_RATE & 110 & 4.75 & 9.50 & 6.7159 & 1.10123 \\
EXCHANGE_RATE & 110 & 8508 & 14657 & 10968.69 & 1831.437 \\
JAKPROP & 110 & 96.03 & 580.71 & 336.1771 & 156.04688 \\
Valid N (listwise) & 110 & & & & \\
\hline
\end{tabular}

Menurut tabel data statistik deksriptif variable maka dapat diketahui nilai minimum dan maksimum untuk variable PDB menunjukan nilai sebesar $4.31 \%-6.81 \%$, nilai rata-rata sebesar $5.5 \%$ dan standar deviasi sebesar 0.72. Berdasarkan data tersebut maka tingkat pertumbuhan di Indonesia pada periode 2008-2017 tergolong melambat dikarenakan terjadi penurunan tajam harga-harga komoditi, turunnya pasar saham dan melemahnya nilai tukar rupiah. Perekonomian Indonesia masih dapat tumbuh disebabkan oleh sektor ekspor Indonesia yang relatif terbatas terhadap perekonomian nasional, kepercayaan pasar yang tinggi dan berlanjutnya konsumsi domestik. Konsumsi domestik di Indonesia (terutama konsumsi pribadi) berkontribusi untuk 55\% dari total pertumbuhan ekonomi negara ini.

Deskriptif statistik pada tingkat inflasi menunjukan nilai minimum dan maksimum untuk variable inflasi menunjukan nilai sebesar $2.41 \%$ - $12.14 \%$, nilai rata-rata sebesar $5.6 \%$ dan standar deviasi sebesar 2.3. Nilai tersebut menunjukan bahwa tingkat inflasi di Indonesia pada periode 2008-2017 memiliki nilai inflasi yang tinggi dengan rata - rata diatas 5\%. Tingkat inflasi yang tinggi menunjukan kecendrungan naiknya harga-harga umum barang dan jasa yang berlangsung secara terus menerus.

Deskriptif statistik untuk tingkat suku bunga yang diukur dengan menggunakan suku bunga Bank Indonesia menunjukan nilai minimum dan maksimum untuk variable tingkat suku bunga menunjukan nilai sebesar $4.75 \%-9.5 \%$, nilai rata-rata sebesar $6.7 \%$ dan standar deviasi sebesar 1.1. Melihat perubahan suku bunga Bank Indonesia dapat diketahui stabilitas yang lebih baik dikarenakan tingkat suku bunga mengindikasi jumlah uang yang beredar dan berputar di masyarakat serta beban pemerintah atas tanggungan utang. Rata-rata tingkat suku Bunga sebesar $6.7 \%$ dipandang sebagai angka yang wajar dan mengindikasi bahwa perekonomian Indonesia untuk periode 2008 - 2017 termasuk dalam kategori lancar.

Deskriptif statistik untuk nilai tukar rupiah terhadap dolar (USD) menunjukan nilai minimum dan maksimum dalam angka Rp.8508 - Rp.14657 dengan rata-rata sebesar Rp.10968. Nilai tersebut menunjukan nilai rupiah yang terus menerus melemah terhadap nilai dolar selama kurun waktu 2008-2017. Melemahnya nilai tukar menunjukan bahwa secara makro tingkat perdagangan berupa ekspor dan impor melemah, penurunan nilai ekspor memicu peningkatan nilai tukar dolar terhadap rupiah.

Deskriptif statistik untuk Indeks harga saham sektor properti (JAKPROP) menunjukan nilai minimum sebesar 96.03 dan maksimum sebesar 580.71, nilai rata-rata indeks yakni sebesar 336.17. Hal ini menunjukan peningkatan yang cukup baik dan merupakan salah faktor yang mendorong perdagangan efek di lantai bursa dan mampu menyerap investor sehingga mampu meningkatkan nilai indeks. 


\section{Hasil Analisis Regresi Berganda}

\section{Tabel 2}

Hasil Regresi Berganda

\begin{tabular}{|c|c|c|c|c|c|c|c|c|c|c|}
\hline \multirow{2}{*}{\multicolumn{2}{|c|}{ Model }} & \multicolumn{2}{|c|}{ Unstandardized Coefficients } & \multirow{2}{*}{$\begin{array}{c}\begin{array}{c}\text { Standardized } \\
\text { Coefficients }\end{array} \\
\text { Beta }\end{array}$} & \multirow[b]{2}{*}{$\mathrm{t}$} & \multirow[b]{2}{*}{ Sig. } & \multicolumn{2}{|c|}{$95.0 \%$ Confidence Interval for B } & \multicolumn{2}{|c|}{ Collinearity Statistics } \\
\hline & & B & Std. Error & & & & Lower Bound & Upper Bound & Tolerance & VIF \\
\hline \multirow[t]{5}{*}{1} & (Constant) & -402.926 & 191.921 & & -2.099 & .038 & -783.469 & -22.382 & & \\
\hline & PDRB & 38.994 & 18.488 & 181 & 2.109 & .037 & 2.335 & 75.653 & .405 & 2.472 \\
\hline & INFLASI & 1.275 & 6.201 & .019 & .206 & .838 & -11.022 & 13.571 & .355 & 2.815 \\
\hline & BI_RATE & -46.545 & 12.838 & -.328 & -3.626 & .000 & -72.000 & -21.091 & 364 & 2.748 \\
\hline & EXCHANGE_RATE & .076 & .007 & .888 & 11.000 & .000 & .062 & .089 & .459 & 2.180 \\
\hline
\end{tabular}

Persamaan regresi berganda menunjukan besarnya pengaruh dari masing - masing variabel independen terhadap variabel dependen, berdasarkan hasil analisis regresi berganda maka didapatkan pesamaan:

Indeks Harga Saham JAKPROP = -402.92 + 38.99 PDB + 1.27 Inflasi - 46.54 BI-Rate + 0.076 Nilai Tukar Rupiah

\section{Uji Koefisien Determinasi R Square}

\section{Tabel 3}

Tabel Hasil Uji Determinasi

Model Summary

\begin{tabular}{|c|c|c|c|c|c|c|c|c|c|c|}
\hline \multirow[t]{2}{*}{ Model } & \multirow[b]{2}{*}{$\mathrm{R}$} & \multirow[b]{2}{*}{ R Square } & \multirow[b]{2}{*}{$\begin{array}{l}\text { Adjusted R } \\
\text { Square }\end{array}$} & \multirow[b]{2}{*}{$\begin{array}{l}\text { Std. Error of } \\
\text { the Estimate }\end{array}$} & \multicolumn{5}{|c|}{ Change Statistics } & \multirow[b]{2}{*}{$\begin{array}{l}\text { Durbin- } \\
\text { Watson }\end{array}$} \\
\hline & & & & & $\begin{array}{l}\text { R Square } \\
\text { Change }\end{array}$ & F Change & df1 & $\mathrm{df} 2$ & Sig. F Change & \\
\hline 1 & $.828^{\mathrm{a}}$ & .686 & .674 & 89.03752 & .686 & 57.451 & 4 & 105 & .000 & .242 \\
\hline
\end{tabular}

a. Predictors: (Constant), EXCHANGE_RATE, BI_RATE, PDRB, INFLASI

b. Dependent Variable: JAKPROP

Keputusan: R Square / $\mathrm{R}^{2}$ dalam data penelitian ini sebesar 0.686 atau dalam persentase sebesar $67.4 \%$ sehingga variasi variabel dependen (Indeks Harga Sektor Properti JAKPROP) dapat dijelaskan oleh variabel Independen (PDB, Inflasi, Bi-Rate, Nilai Tukar IDR/USD) sebesar $67.4 \%$ sedangkan sisanya $32.6 \%$ dijelaskan oleh variabel lain yang tidak diikut sertakan dalam penelitian ini sehingga dapat diteliti kembali dipenelitian berikutnya.

\section{Uji F (Secara Simultan)}

\section{Tabel 4}

Hasil Pengujian Signifikansi Simultan (Uji F)

ANOVA $^{\text {b }}$

\begin{tabular}{|ll|r|r|r|r|l|}
\hline \multicolumn{2}{|l|}{ Model } & \multicolumn{1}{c|}{$\begin{array}{c}\text { Sum of } \\
\text { Squares }\end{array}$} & \multicolumn{1}{c|}{ df } & Mean Square & F & Sig. \\
\hline 1 & Regression & 1821812.117 & 4 & 455453.029 & 57.451 & $.000^{\mathrm{a}}$ \\
& Residual & 832406.460 & 105 & 7927.681 & & \\
& Total & 2654218.576 & 109 & & & \\
\hline
\end{tabular}

a. Predictors: (Constant), EXCHANGE_RATE, BI_RATE, PDRB, INFLASI

b. Dependent Variable: JAKPROP

Hasil uji $\mathrm{F}$ adalah angka tingkat signifikan 0.000. Karena nilai signifikannya lebih kecil dari $\alpha=0.05$, maka Ha diterima dan Ho ditolak. Dapat disimpulkan bahwa dan variabel independennya (PDB, Inflasi, Bi-Rate, Nilai tukar IDR/USD) berpengaruh secara signifikan terhadap variabel dependen Indeks harga saham properti (JAKPROP) dengan tingkat keyakinan $95 \%$ dan model regresi ini layak (fit) untuk digunakan

\section{Uji t Signifikan parameter individual}

Uji statistik t akan digunakan untuk melihat apakah variabel bebas PDB, Inflasi, Bi-Rate, Nilai tukar IDR/USD dapat digunakan untuk memprediksi variabel dependen Indeks harga saham properti (JAKPROP) dengan tingkat keyakinan 95\%.

Dasar keputusan yang digunakan dalam uji $t$ ini adalah nilai signifikansi dari output SPSS. Jika nilai signifikansi $>0.05$, maka Ho diterima dan Ha ditolak. Artinya variabel independen tidak mempengaruhi terhadap signifikan variabel dependen. Jika nilai signifikansi $<0.05$, maka Ho ditolak dan Ha diterima. Berarti variabel memiliki pengaruh signifikan terhadap variabel dependen 
Tabel 5

Uji Koefisien Regresi Berganda Secara Parsial dengan Uji-T

\begin{tabular}{|c|c|c|c|c|c|c|c|c|c|c|}
\hline \multirow[t]{2}{*}{ Mode } & & \multicolumn{2}{|c|}{ Unstandardized Coefficients } & \multirow{2}{*}{$\begin{array}{c}\begin{array}{c}\text { Standardized } \\
\text { Coefficients }\end{array} \\
\text { Beta } \\
\end{array}$} & \multirow[b]{2}{*}{$\mathrm{t}$} & \multirow[b]{2}{*}{ Sig. } & \multicolumn{2}{|c|}{$95.0 \%$ Confidence Interval for B } & \multicolumn{2}{|c|}{ Collinearity Statistics } \\
\hline & & B & Std. Error & & & & Lower Bound & Upper Bound & Tolerance & $\mathrm{VIF}$ \\
\hline \multirow[t]{5}{*}{1} & $\begin{array}{l}\text { (Constant) } \\
\end{array}$ & -402.926 & 191.921 & & -2.099 & .038 & -783.469 & -22.382 & & \\
\hline & PDRB & 38.994 & 18.488 & 181 & 2.109 & .037 & 2.335 & 75.653 & .405 & 2.472 \\
\hline & INFLASI & 1.275 & 6.201 & .019 & .206 & .838 & -11.022 & 13.571 & .355 & 2.815 \\
\hline & BI_RATE & -46.545 & 12.838 & -.328 & -3.626 & .000 & -72.000 & -21.091 & 364 & 2.748 \\
\hline & EXCHANGE_RATE & .076 & .007 & .888 & 11.000 & .000 & .062 & 089 & .459 & 2.180 \\
\hline
\end{tabular}

\section{Hasil dan Pembahasan}

\section{Pengaruh PDB terhadap indeks harga saham sektor properti (JAKPROP)}

Melalui hasil pengujian regresi yang ditunjukan melalui table 4.5 maka dapat diketahui bahwa variabel PDB memiliki nilai signifikansi sebesar $0.037<0.05$, sehingga H1 diterima. Sehingga pertumbuhan PDB berpengaruh secara signifikan dengan tingkat keyakinan 95\% terhadap indeks harga saham sektor properti (JAKPROP). Dengan nilai t-hitung sebesar 2.109 menunjukan pertumbuhan PDB memiliki pengaruh positif terhadap indeks harga saham sektor properti (JAKPROP).

Produk Domestik Bruto (PDB) atau Gross Domestic Product merupakan indikator ekonomi yang paling umum untuk menilai kondisi perekonomian sebuah negara. PDB menggambarkan nilai pasar dari semua barang dan jasa yang diproduksi pada periode waktu terukur.

Peningkatan PDB mempunyai pengaruh positif terhadap daya beli konsumen sehingga dapat meningkatkan permintaan terhadap produk perusahaan. Hal ini merupakan sinyal positif karena pendapatan yang dihasilkan perusahaan meningkat sehingga harga saham pun naik, namun dalam kasus ini indeks harga saham properti ternyata dipengaruhi oleh PDB karena profile dari konsumen yang melakukan investasi properti dapat berasal dari konsumen end user maupun investor sehingga harga saham properti dipengaruhi daya beli konsumen dari pengaruh PDB.

\section{Pengaruh Laju Inflasi terhadap indeks harga saham sektor properti (JAKPROP)}

Melalui hasil pengujian regresi yang ditunjukan melalui table 4.5 dapat dilihat bahwa variabel tingkat inflasi memiliki nilai signifikansi sebesar $0.838>0.05$, sehingga $\mathrm{H} 2$ ditolak. Sehingga dapat diartikan pertumbuhan laju inflasi dengan keyakinan 95\% tidak berpengaruh secara signifikan dengan tingkat indeks harga saham sektor properti (JAKPROP).

Inflasi merupakan suatu indikator ekonomi makro yang menggambarkan kenaikan hargaharga secara umum dalam suatu periode tertentu. Penggunaan tingkat inflasi sebagai salah satu indikator fundamental ekonomi adalah untuk mencerminkan tingkat PDB ke dalam nilai yang sebenarnya. Peningkatan inflasi secara relatif merupakan sinyal negatif bagi pasar saham.

Menurut Sharpe, Alexander, Bailey (1997) return saham relative tinggi saat inflasi relative tinggi dan relative rendah saat inflasi relative rendah, karena seiring dengan naiknya inflasi, saham merepresentasikan meningkatnya nilai klaim asset nyata. Menurut Samsul (2006;201) pengaruh positif atau pun negative dari peningkatan inflasi tergantung dari tingkat inflasi tersebut. Dengan meningkatnya inflasi, akan meningkatkan pendapatan dan biaya perusahaan.

Menurut (Tandelilin, 1999;214). Peningkatan biaya oleh perusahaan menyebabkan profitabilitas perusahaan akan turun. Namun untuk industry sektor bahan baku ataupun industry bahan bakar, akan mengalami pengaruh positif karena naiknya harga bahan baku mereka memberikan keuntungan yang mereka dapatkan dari pendapatan yang tinggi.

Saat terjadinya peningkatan inflasi yang tak terkendali, maka akan memberikan efek meningkatkanya biaya operasional para pengusaha yang terdaftar di BEI karena adanya kenaikan harga bahan baku, gaji karyawan, dll. Sehingga dikhawatirkan menurunnya laba bersih pada emiten. Dan jika hal ini terjadi pada banyak saham di pasar modal maka indeks harga saham sektor gabungan (IHSG) secara keseluruhan akan turun jadi indeks harga saham 
sektor properti dapat bangkit kembali saat inflasi diharapkan terkendali dengan dinaikanya BiRate.

Pengaruh Tingkat Suku Bunga BI terhadap indeks harga saham sektor properti (JAKPROP)

Melalui hasil pengujian regresi yang ditunjukan melalui table 4.5 dapat dilihat bahwa variabel BI-Rate memiliki nilai signifikansi sebesar $0.00<0.05$ sehingga $\mathrm{H} 3$ diterima. Berarti pertumbuhan BI Rate mempengaruhi secara signifikan dengan tingkat keyakinan 95\% terhadap indeks harga saham properti (JAKPROP).

Salah satu cara pemerintah dalam menanggulangi inflasi adalah dengan melakukan kebijakan menaikkan tingkat suku bunga. Tingkat suku bunga yang tinggi merupakan sinyal negatif terhadap harga saham. Hubungan antara tingkat bunga dengan pergerakan harga saham adalah berlawanan. Tingkat suku bunga yang meningkat akan menyebabkan peningkatan suku bunga yang disyaratkan atas investasi pada suatu saham. Tingkat suku bunga yang meningkat bisa juga menyebabkan investor menarik investasinya pada saham dan memindahkannya pada investasi, misalnya pada obligasi. Karena investor mengurangi portofolio saham dengan melepas saham, maka supply saham di pasar saham meningkat dan selanjutnya akan menyebabkan penurunan harga saham tersebut.

Menurut samsul (2006;201) dengan meningkatnya suku Bunga akan mendorong investor untuk menjual saham dan kemudian menabung hasil penjualanya itu ke dalam deposito. Harga saham di bursa akan menurun akibat penjualan saham secara besar besaran tersebut. Hal ini terbukti pada penelitian ini yang memiliki t-hitung negative sehingga dengan meningkatnya Bi-Rate sebesar $1 \%$ makan dengan asumsi variable lain dianggap konstan (nol), maka Indeks harga sektor properti (JAKPROP) akan mengalami penurunan sebesar $-32.8 \%$.

Pengaruh Nilai Tukar Rupiah terhadap Dollar Amerika terhadap indeks harga saham sektor properti (JAKPROP)

Melalui hasil pengujian regresi yang ditunjukan melalui table 4.5 dapat dilihat bahwa variabel Nilai Tukar IDR/USD memiliki nilai signifikansi sebesar $0.00<0.05$ sehingga H4 diterima. Berarti pertumbuhan nilai tukar IDR/USD mempengaruhi secara signifikan dengan tingkat keyakinan 95\% terhadap indeks harga saham properti (JAKPROP).

Menguatnya nilai tukar Rupiah terhadap mata uang asing merupakan sinyal positif bagi perekonomian yang mengalami inflasi. Menurut Tarigan (2007), bahwa nilai tukar berpengaruh positif terhadap harga saham. Semakin tinggi nilai tukar Rupiah terhadap mata uang asing (apresiasi), maka harga saham juga akan meningkat.

Menguatnya kurs Rupiah terhadap mata uang asing akan menurunkan biaya impor bahan untuk produksi dan akan menurunkan tingkat suku bunga yang berlaku. Pada umumnya saat terjadi perubahan nilai kurs IDR akan berdampak perubahan nilai investasi saham pada mata uang investor asing dalam USD yang akan menyebabkan keuntungan / kerugian akan mempengaruhi keputusan investor asing dalam berinvestasi di Bursa Efek Indonesia sehingga mempengaruhi pergerakan Indeks harga saham sektor properti (JAKPROP).

Pengaruh Pertumbuhan PDB, Laju Inflasi, Tingkat Suku Bunga BI, Nilai Tukar Rupiah terhadap Dollar Amerika terhadap indeks harga saham sektor properti (JAKPROP)

Melalui hasil pengujian regresi yang ditunjukan melalui table 4.5 dapat dilihat bahwa variabel Pertumbuhan PDB, Laju Inflasi, Tingkat Suku Bunga BI, Nilai Tukar Rupiah terhadap Dollar Amerika memiliki nilai signifikansi sebesar 0.038<0.05 sehingga H5 diterima. Berarti Pertumbuhan PDB, Laju Inflasi, Tingkat Suku Bunga BI, Nilai Tukar Rupiah terhadap Dollar Amerika secara parsial dan secara bersama terhadap indeks harga saham property mempengaruhi secara signifikan dengan tingkat keyakinan 95\% terhadap indeks harga saham properti (JAKPROP). Prospek industri properti memang sulit ditebak karena Sektor properti merupakan sektor yang rentan terhadap perubahan dalam perekonomian berbagai prospek tersebut memerlukan banyak sekali asumsi - asumsi yang harus dipenuhi. 


\section{KESIMPULAN}

Berdasarkan hasil penelitian yang dilakukan oleh peneliti pada periode 2008-2017 maka dapat di simpulkan hasilnya yakni sebagai berikut:

1. Pertumbuhan PDB merpengaruhi secara signifikan terhadap indeks haga saham sektor property JAKPROP.

2. Tingkat Inflasi tidak mempengaruhi secara signifikan terhadap indeks haga saham sektor property JAKPROP.

3. Tingkat BI-Rate mempengaruhi secara signifikan terhadap indeks haga saham sektor property JAKPROP.

4. Nilai Tukar IDR/USD mempengaruhi secara signifikan terhadap indeks haga saham sektor property JAKPROP.

5. Pertumbuhan PDB, Laju Inflasi, Tingkat Suku Bunga BI, Nilai Tukar Rupiah terhadap Dollar Amerika mempengaruhi secara signifikan terhadap indeks haga saham sektor property JAKPROP.

\section{DAFTAR RUJUKAN}

Adam, T. (2006). Macroeconomic factors and stock market movement: Evidence from ghana. school of management. MPRA Paper No. 13699, posted 2 March 2009. University of Leicester, UK.

Algifari. (1997). Analisis Statistik untuk Bisnis dengan Regresi, Korelasi Dan Nonparametrik Algifari (Edisi 1, Cetakan 1). Yogyakarta STIE-YKPN.

Ang, R. (1997). Pasar Modal Indonesia. Jakarta: Mediasoft.

Bahmani-Oskooée, M., \& Sohrabian. (1992). Stock prices and the effective exchange rate of the dollar". Applied Economics, 24, 459-464.

Boediono. (2012). Pengantar Ilmu Ekonomi No.2 Ekonomi Makro, Seri Sinopsis (Edisi Kedua Puluh Empat). Yogyakarta: BPFE.

Dernburg, T. F. (2009). Makro Ekonomi. Jakarta: Penerbit Erlangga.

Digilib.unimed.ac.id. (2013). Pengaruh Inflasi Suku Bunga Sbi dan Pertumbuhan Pdb terhadap Indeks Harga Saham Gabungan di bursa efek indonesia tahun 2008-2012 Retreived September 30, 2014

Dornbusch, R. \& Fischer. (2004). Macro Economics (9 $9^{\text {th }}$ ed.). New York: McGraw-Hill Companies

Fuadi, D. W. (2009). Analisis pengaruh suku bunga, volume perdagangan dan kurs terhadap return saham sektor properti yang listed di BEI periode 2003-2007. Skripsi Sarjana Jurusan Manajemen pada Fakultas Ekonomi. Semarang: Universitas Diponegoro.

Gilarso, T. (1992). Pengantar Ilmu Ekonomi Makro. Yogyakarta: Penerbit Kanisus.

Kompas, (2003), Investasi Saham Properti Sudah Layak Ditengok, 27 mei, p. 27

Mankiw, N. G. (2003). Teori Makroekonomi (Edisi Kelima). Jakarta: Penerbit Erlangga.

Samuelson, P.A. \& Nordhaus, W.D. (2004). Ilmu Makroekonomi (Edisi Tujuh Belas). Jakarta: PT. Media Global Edukasi.

Tandelilin, E. (2010). Portofolio dan Investasi (Edisi Pertama). Yogyakarta: Penerbit Kanisius. 